\title{
ANALISIS EVALUATIF PENERAPAN AGENDA MASYARAKAT ASEAN 2015 DI BIDANG PARIWISATA DI WILAYAH SULAWESI BARAT 2015-2018
}

\author{
Muhammad Rizky Prawira \& Asma Amin
}

\begin{abstract}
The year of 2018 is a sign that the implementation of the ASEAN Community agenda has entered its third year. In other words, by now we can expect to see the progress of the integrated programs from the ASEAN Community. More specifically, the initial output from the development of the tourism sector in suburban and rural areas in Indonesia should now be assessible. Based on these considerations, this research is initiated. In this case, West Sulawesi is definitely a province that is still relatively young and includes several districts and many villages that are still developing. But on the other hand, the province actually has a considerable potential in tourism, especially in terms of developing natural and coastal tourism sites. Therefore, using a combination of structured interview and process tracing methods, this study analyzes the outputs and initial results of tourism development in West Sulawesi for three years since the start of ASEAN Community in 2015. The results of the study indicate that there has not been a significant increase or strategic improvement in the development of tourism infrastructures in West Sulawesi during the period of 2015-2018. But on the other hand, there is a significant increase in the number of foreign tourists in West Sulawesi during this period which is mainly generated by the application of event-based tourism activities.
\end{abstract}

Key Words: ASEAN Community, Tourism, West Sulawesi Tourism.

\section{PENDAHULUAN}

\section{Latar Belakang}

Pada akhir tahun 2015, organisasi regional yang menaungi negaranegara di kawasan Asia Tenggara, Association of Southeast Asian Nations (ASEAN), telah secara resmi meluncurkan suatu agenda besar yang dinamakan Masyarakat ASEAN (ASEAN Community), atau juga dikenal sebagai 
Masyarakat Ekonomi ASEAN. Masyarakat ASEAN sendiri merupakan suatu kerangka kerjasama regional antar negara-negara anggota ASEAN yang dimaksudkan untuk mencapai tujuan-tujuan yang tercakup dalam tiga pilar utama, yaitu politik-keamanan, ekonomi, dan sosial budaya. Dari sisi penerapannya sendiri, Masyarakat ASEAN menitikberatkan pada penciptaan suatu pola interaksi koperatif antar negara-negara anggota yang lebih open serta integratif. Dalam hal ini, konektivitas serta keterpaduan menjadi katakata kunci.

Lebih jauh, isu konektivitas serta perpindahan manusia lintas batas negara tentu saja tidak dapat terlepas dengan sektor pariwisata. Dalam hal ini, pariwisata menjadi salah satu aspek yang menjadi perhatian serius dalam mencapai Konektivitas ASEAN (ASEAN Connectivity) yang juga menjadi elemen penting dari agenda Masyarakat ASEAN secara keseluruhan. Secara lebih khusus, fokus dari pengembangan sektor kepariwisataan ini tentu lebih terarah pada daeah-daerah dimana situs-situs pariwisata dapat dikembangkan lebih jauh serta wilayah-wilayah dimana taraf hidup masyarakat perlu untuk diperhatikan. Dalam hal ini, dapat dikatakan bahwa wilayah rural, sub-urban, serta pedesaan mendapatkan porsi tersendiri.

Tahun 2018 ini menjadi penanda bahwa penerapan grand project Masyarakat ASEAN telah memasuki tahun ketiga. Dengan kata lain, kemajuan dari penerapan program-program terpadu dari Masyarakat ASEAN seharusnya sudah mulai terlihat. Secara lebih terkhusus, output awal dari pengembangan sektor pariwisata di wilayah rural, sub-urban dan pedesaan di Indonesia seharusnya sudah dapat diukur. Berdasarkan pertimbangan-pertimbangan tersebut, penelitian ini diinisiasikan. Dalam hal ini, Sulawesi Barat jelas merupakan provinsi yang masih tergolong muda dan mencakup beberapa kabupaten serta banyak desa yang dapat dikatakan masih dalam tahap pembangunan dan belum semapan beberapa provinsi-provinsi lain yang telah lebih dulu melakukan pembangunan. Namun di sisi lain, Provinsi Sulawesi Barat sebenarnya memiliki potensi yang cukup besar di bidang pariwisata, khususnya dalam hal pengembangan situs situs wisata laut, pantai, serta 
wilayah pesisir. Maka dari itu, penelitian ini akan mencoba untuk menganalisis output serta hasil sementara dari upaya pengembangan pariwisata di wilayah Sulawesi Barat selama tiga tahun sejak dimulainya Masyarakat ASEAN pada 2015. Tujuan dari penelitian ini adalah sebagai berikut:

1. Mengetahui output atau dampak terkini dari pengembangan sektor pariwisata terkait agenda Masyarakat ASEAN 2015 di wilayah Sulawesi Barat

2. Mengevaluasi efektifitas upaya pengembangan sektor pariwisata terkait agenda Masyarakat ASEAN 2015 di wilayah Sulawesi Barat sepanjang periode 2015-2018.

\section{Urgensi Penelitian}

Penelitian ini dapat memberikan kontribusi dalam dua ranah utama. Pertama, penelitian ini dapat memberikan gambaran bagi para akademisi, peneliti serta masyarakat baik secara umum, maupun yang secara khusus berkecimpung di ranah pariwisata mengenai kemajuan, output, serta hasil terkini yang dapat terlihat dari pengembangan sektor pariwisata di wilayah Sulawesi Barat sejak diberlakukannya Masyarakat ASEAN 2015. Kedua, melalui analisis evaluatif, penelitian ini dapat menjadi acuan bagi pemerintah, khususnya Pemerintah Daerah Sulawesi Barat, Dinas Pariwisata Sulawesi Barat, serta seluruh stakeholders pariwisata di wilayah ini tentang aspekaspek potensial yang masih dapat dikembangkan lebih lanjut terkait pengembangan sektor pariwisata dalam mencapai visi dan misi dari Masyarakat ASEAN 2015.

\section{TINJAUAN PUSTAKA}

Integrasi Regional

Proses integrasi yang semakin intensif di tubuh ASEAN terbukti membawa berbagai dampak, seperti peningkatan pertumbuhan ekonomi yang 
signifikan di negara-negara ASEAN (Bong \& Premaratne, 2018) dan peningkatan konektifitas penduduk ASEAN sendiri dalam beberapa tahun terkahir. Dalam hal ini, ASEAN telah menjadi organisasi yang siap untuk lebih jauh menyatukan negara-negara anggotanya melalui kerangka interaksi yang semakin terbuka, inklusif, dengan peningkatan dalam konektivitas antar warganya. Sebagaimana Uni Eropa yang telah lebih dulu sukses mengintegrasikan masyaraktnya, ASEAN dewasa ini, khususnya dalam konteks penerapan Masyarakat ASEAN bisa dikatakan juga telah merefleksikan kerangka praktis dari konsep serta teori integrasi regional. Lebih jauh, dalam teori integrasi sendiri terdapat beberapa bentuk integrasi regional yang diklasifikasikan berdasarkan karakteristiknya, seperti integrasi yang bersifat transaksionalis, neo-fungsionalis, liberalis, realis, dsb. Namun dalam menelaah Masyarakat ASEAN, secara spesifik kita dapat merujuk pada konsep integrasi regional neo-fungsionalisme dan liberalisme.

\section{Neo-fungsionalisme}

Integrasi dalam pengertian politik dapat diartikan sebagai "suatu proses penyatuan dua unit politik atau lebih dimana terjadi suatu pendirian komunitas politik melalui suatu pembentukan aturan-aturan kolektif, serta institusi bersama yang memiliki otoritas dalam perumusan kebijakan serta memproyeksikan identitas komunitas secara terpadu dan tidak lagi sekedar identitas pribadi antar unit per unit" (Illievski, 2015, p. 2). Selain itu, suatu proses integrasi politik akan menuntut negara-negara ini untuk menyerahkan sedikit loyalitas serta kedaulatan nasionalnya untuk pembentukan insitusi sentral yang memiliki yuridiksi dengan potensi cakupan melintasi yuridiksi nasional dari negara-negara ini (Haas, 1968, p.16).

Secara terkhusus, perspektif neo-fungsionalisme menekankan pada kepentingan bersama serta kebutuhan bersama yang dimiliki oleh beberapa negara yang kemudian diartikulasikan dalam bentuk integrasi global/regional (Rosamund, 2000). Neo-fungsionalisme sendiri dapat dikatakan memiliki tujuan untuk membentuk "suatu kerangka atau jejaring yang 
menghubungkan negara-negara dalam suatu institusi supranasional" (Illievski, 2015, p. 5). Sebagai hasilnya, jejaring antar negara ini akan menciptakan suatu pola interaksi saling membutuhkan (inter-dependen) satu sama lain, yang sangat berpotensi menjadi jaminan untuk pemeliharan perdamaian antar negara-negara ini. (Illievski, 2015a.).

Lebih jauh, neo fungsionalisme tidak berfokus pada suatu kondisi yang tetap atau fixed melainkan pada suatu proses yang berkelanjutan. Dalam hal ini, neo-fungsionalisme mengenal proses spill-over dalam integrasi regional. Secara garis besar, spill-over dalam hal ini bersinggungan dengan beberapa tahapan proses integrasi regional, yang diawali dengan dimulainya kerjasama non-formal antar negara-negara kawasan, lalu dilanjutkan dengan dibentuknya institusi, kemudian dilakukan penyerahan sebagian dari kedaulatan nasional serta dibentuk aturan-aturan bersama yang mengikat hingga berakhir pada terciptanya suatu komunitas politik yang benar-benar terpadu (Castaldi 2007; Heinonen 2006; Illievski 2015; Kovacevic 2013). Di samping itu, spillover dalam hal ini juga berkaitan dengan ranah atau bidang dimana proses kerjasama dalam suatu konteks integrasi regional ini dilakukan. Dalam hal ini, suatu kerjasama antar negara-negara kawasan dalam suatu sektor, sangat mungkin untuk berlanjut di sektor-sektor lain yang dirasa penting untuk dibenahi secara bersama (Castaldi et al, 2007a).

\section{Intergovernmentalisme Liberal}

Intergovernmentalisme liberal mewakili perspektif integrasi regional yang menekankan pada proses bargaining atau saling tawar menawar kepentingan antar negara-negara dalam suatu kawasan tertentu. Dalam hal ini proses bargaining dilakukan atas dasar suatu kepentingan atau preferensi negaranegara terkait yang dibangun dari level domestik atau nasional. Sebagaimana dinyatakan oleh Moravcsik (1991), negara membawa kekuatan relatif serta preferensi masing-masing dan mencoba menegosiasikannya di ranah regional. Situasi saling tawar menawar ini akhirnya menciptakan suatu pola interaksi 
yang interdependen antar negara-negara ini yang akhirnya diaktualisasikan dalam bentuk kebijakan-kebijakan di level institusional.

Lebih jauh, Moravcsik (1998) menjabarkan bahwa terdapat beberapa tahapan utama dalam pembentukan suatu kerangka kerjasama internasional. Dalam hal ini, pemerintahan negara-negara terkait akan terlebih dulu menetapkan preferensi atau prioritas kepentingan dalam negeri untuk di bawa ke ranah internasional, lalu kemudian melibatkan diri dalam proses tawarmenawar atau bargaining dengan negara lain yang juga membawa preferensi domestiknya (Moravcsik, 1998, p. 24). Proses interaksi ini akhirnya berujung pada terciptanya suatu titik temu berupa pilihan institusional dimana negaranegara ini akan menyerahkan sebagian kedaulatan nasionalnya kepada institusi regional atau internasional (Moravcsik, 1998a).

\section{Konektivitas dan Pariwisata}

Suatu bentuk kerangka kerjasama dalam payung integrasi regional seperti Masyarakat ASEAN senantiasa menekankan fokus programnya pada pengembangan konektivitas masyarakat negara-negara anggotanya. Secara lebih spesifik, konektivitas ASEAN bertujuan untuk menghubungkan serta menyatukan ASEAN melalui pengembangan dalam konektivitas infrastruktur (mencakup pembangunan fasilitas transportasi, dsb), konektivitas institusional (meliputi kerangka kerjasama formal di tingkat institusi serta perumusan kebijakan dan regulasi berkaitan dengan mobilitas lintas batas ASEAN) dan konektivitas orang per orang (people to people connectivity) (ASEAN, 2011). Secara terkhusus, sektor pariwisata merupakan cakupan dari people to people connectivity dan menjadi suatu isu yang menjadi perhatian ASEAN dengan fokus utama adalah mencapai peningkatan kerjasama pariwisata antar negara-negara ASEAN, peningkatan jumlah turis melebihi kawasan lain, serta terjaganya keberlanjutan (sustainability) sektor pariwisata di ASEAN (Akkapin \& Srithamasak, 2019, p. 3). 
Lebih jauh, pariwisata pada dasarnya mencakup isu turis, destinasidestinasi wisata, serta segala proses yang meliputi interaksi antara kedua aspek ini. Proses dalam hal ini dapat dikatakan merujuk pada segala aktifitas perpindahan, persinggahan dan perlintasan sementara manusia di wilayahwilayah di luar tempat asalnya dengan tujuan-tujuan selain untuk bekerja atau mencari penghidupan (Fandeli, 1995). Sehubungan dengan ini, Goeldner dan Ritchie (2009, p. 6) menjabarkan secara lebih spesifik bahwa pariwisata meliputi segala "proses, aktifitas, dan dampak serta akibat yang timbul dari hubungan serta interaksi antara antara turis, penyalur turis, pemerintah sebagai tuan rumah, masyarakat dan komunitas sebagai tuan rumah, serta lingkungan-lingkungan yang terlibat dalam proses penerimaan serta penjamuan turis". Dari pengertian ini, jelas bahwa pariwisata bukan hanya menyangkut situasi persinggahan wisatawan di suatu tempat tertentu, namun juga berkaitan erat dengan bagaimana masyarakat serta pemerintah berstrategi dalam menawarkan, dan memasarkan destinasi serta pelayanan pariwisata bagi para turis, baik di wilayah perkotaan maupun di area rural ataupun pedesaan.

Di Indonesia sendiri program-program berorientasi pariwisata di wilayah pedesaan telah mulai dicanangkan sebagai upaya terpadu dalam mensukseskan agenda Masyarakat ASEAN 2015. Beberapa bentuk diantaranya adalah seperti pengembangan desa wisata dengan memperhatikan aspek-aspek seperti inovasi dalam pelayanan, baik itu dalam teknologi produk dan jasa pariwisata, pengembangan lingkungan pariwisata berbasis konservasi dan ecotourism, serta inovasi dalam pengembangan komoditas serta produk kewirausahaan pedesaan yang bernilai tinggi (Nugroho \& Negara, 2014). Berbagai langkah ini bisa dikatakan merupakan bagian dari upaya terpadu ASEAN bersama pemerintah Indonesia sebagaimana tergambar dalam Rencana Strategis Pariwisata ASEAN, khususnya dalam aspek pengembangan produk pariwisata dan peningkatan pelayanan dan sumber daya manusia (Moenir, 2017). Selain untuk memberikan kesiapan bagi daerah dan masyarakat pedesaan dalam menghadapi arus Masyarakat ASEAN, langkah- 
langkah ini tentu saja juga dimaksudkan agar pedesaan di Indonesia mampu untuk mendapatkan benefit maksimal dari pemanfaatan sektor pariwisata demi menyongsong ASEAN yang semakin terintegrasi.

\section{METODOLOGI}

\section{Metode Penelitian}

Metode yang akan digunakan dalam penelitian ini adalah metode kualitatif. Secara lebih khusus penelitian ini akan menggunakan kombinasi antara metode wawancara terstruktur dan process tracing atau pelacakan proses. Wawancara terstruktur merupakan proses wawancara yang dilakukan, dimana topik serta pertanyaan telah diatur terlebih dahulu dan diarahkan untuk menjawab isu-isu spesifik yang telah dirumuskan sebelumnya. Metode wawancara ini tepat untuk dilakukan kepada para birokrat, pejabat, serta figur elit dengan tujuan untuk menggali informasi spesifik mengenai kebijakan, aktifitas dan kemajuan program yang menjadi cakupan otoritas narasumber yang bersangkutan.

Metode kedua yang akan digunakan dalam penelitian ini adalah process tracing dan pelacakan proses. Process tracing merupakan suatu metode analisis kualitatif yang dilakukan dengan "mencari tahu dan mendalami buktibukti empiris dalam suatu isu atau fenomena yang spesifik" (Bennett, 2008, p.705). Dalam metode process tracing, suatu penjelasan historis dengan elaborasi peristiwa secara kronologis akan suatu isu khusus diharapkan dapat dicapai (Bennett, 2008a). Lebih jauh, process tracing sangat mungkin diaplikasikan untuk menguji suatu hubungan kausal atau sebab akibat antar variable-variabel diteliti serta mencari tahu jika terdapat relasi kausal akan variable-variabel yang telah ditentukan melalui pendekatan teoritis ataupun ekspektasi sebelumnya. 


\section{Operasionalisasi Variabel}

Penelitian ini menggunakan dua variabel, yaitu variabel independen dan variabel dependen. Secara spesifik, variabel independen yang digunakan dalam penelitian ini adalah Masyarakat ASEAN atau penerapan agenda Masyarakat ASEAN 2015 di bidang pariwisata di wilayah Sulawesi Barat. Di sisi lain, variabel dependen dalam penelitian ini adalah perkembangan sektor pariwisata di wilayah Sulawesi Barat pada periode 2015-2018 dalam kaitannya dengan Masyarakat ASEAN dan Konektivitas ASEAN. Dalam hal ini, indikator yang paling mungkin untuk diukur adalah gambaran sarana-prasarana, serta pelayanan pariwisata dan situs-situs pariwisata di wilayah Sulawesi Barat dalam periode ini. Di samping itu, indikator kedua adalah frekuensi dan intensitas turis atau wisatawan yang melakukan kunjungan ke Sulawesi Barat dalam periode ini dimana peningkatan jumlah turis jelas berbanding lurus dengan perkembangan sektor pariwisata secara umum.

\section{Data dan Sampel}

Data yang digunakan dalam penelitian ini adalah gabungan antara data primer dan data sekunder. Data primer dalam hal ini tentu merupakan hasil wawancaraa langsung dengan para pejabat serta pihak-pihak yang berwenang dalam kaitannya dengan pengembangan pariwisata di Sulawesi Barat. Data sekunder merupakan informasi serta data yang dikumpulkan tentang pariwisata di Sulawesi Barat dari berbagai literatur, artikel, sumber berita online, dokumen, laporan, dan sebagainya. Sedangkan teknik penentuan sampel adalah purposive sampling dimana sampel atau dalam hal ini narasumber dalam penelitian ini telah ditentukan secara spesifik sebelumnya sesuai dengan fungsi serta tujuan informasi yang ingin didapatkan.

Tabel 1: Operasionalisasi Variabel

No. Variabel
Indikator variabel 


\begin{tabular}{|c|c|c|}
\hline 1 & $\begin{array}{l}\text { Variabel } \text { Independen } \\
\text { Penerapan agenda Masyarakat } \\
\text { ASEAN di sektor pariwisata }\end{array}$ & $\begin{array}{l}\text { Agenda Masyarakat ASEAN di } \\
\text { sektor pariwisata }\end{array}$ \\
\hline 2 & $\begin{array}{lr}\text { Variabel } & \text { Dependen: } \\
\text { Perkembangan } & \text { sektor } \\
\text { pariwisata di wilayah } & \text { Sulawesi } \\
\text { Barat 2015-2018 } & \end{array}$ & $\begin{array}{l}\text { (1) Infrastruktur dan sarana } \\
\text { prasarana pariwisata, serta } \\
\text { pelayanan pariwisata 2015-2018; } \\
\text { (2) Intensitas kunjungan dan } \\
\text { kuantitas turis mancanegara dan } \\
\text { negara-negara ASEAN di wilayah } \\
\text { Sulawesi Barat sepanjang 2015- } \\
2018\end{array}$ \\
\hline
\end{tabular}

PEMBAHASAN

Pengembangan infrastruktur pariwisata: jumlah hotel dan akomodasi

Salah satu instrumen pendukung utama dalam peningkatan aspek pariwisata daerah adalah ketersediaan akomodasi, baik itu hotel maupun penginapan. Tempat menginap merupakan fasilitas yang sangat penting dalam memastikan kenyamanan para wisatawan atau calon wisatawan, yang juga akan berujung pada tingkat frekuensi kunjungan. Di wilayah Sulawesi Barat sendiri, fasilitas akomodasi mengalami fluktuasi dari segi jumlah meskipun tidak signifikan. Terdapat 145 hotel dan penginapan di seluruh wilayah Sulawesi Barat pada tahun 2015 dan meningkat menjadi 147 pada 2016 (BPS, 2017). Jumlah ini pun naik hingga 155 pada 2017 dan turun kembali ke 150 pada 2018 (BPS 2018;

BPS, 2019).

Tabel 2: Jumlah akomodasi/hotel di wilayah Sulawesi Barat 2015-2018

\begin{tabular}{|c|c|c|c|c|}
\hline \multirow{2}{*}{$\begin{array}{c}\text { Kabupaten } \\
\text { /Kota }\end{array}$} & \multicolumn{4}{|c|}{ Jumlah Hotel/Penginapan } \\
\cline { 2 - 5 } & $\mathbf{2 0 1 5}$ & $\mathbf{2 0 1 6}$ & $\mathbf{2 0 1 7}$ & $\mathbf{2 0 1 8}$ \\
\hline Majene & 17 & 19 & 18 & 17 \\
\hline $\begin{array}{c}\text { Polewali } \\
\text { Mandar }\end{array}$ & 21 & 23 & 25 & 24 \\
\hline
\end{tabular}




\begin{tabular}{|c|c|c|c|c|}
\hline Mamasa & 23 & 19 & 22 & 22 \\
\hline Mamuju & 51 & 54 & 58 & 57 \\
\hline Pasangkayu & 19 & 19 & 18 & 17 \\
\hline $\begin{array}{c}\text { Mamuju } \\
\text { Tengah }\end{array}$ & 14 & 13 & 14 & 13 \\
\hline Total & 145 & 147 & 155 & 150 \\
\hline
\end{tabular}

Sumber: Dinas Pariwisata Sulawesi Barat

Jika kita melihat data tersebut secara sekilas, dapat dikatakan bahwa momentum Masyarakat ASEAN 2015 seolah-olah diikuti oleh peningkatan jumlah akomodasi di wilayah Sulawesi Barat. Meskipun begitu, jumlah peningkatan yang tidak signifikan cenderung lebih tepat diasosiakan sabagai suatu bentuk pertumbuhan yang berjalan secara normal dibandingkan dengan pertumbuhan yang secara khusus didorong oleh agenda besar Masyarakat ASEAN. Hal ini juga didukung oleh fakta bahwa tingkat jumlah akomodasi dan hotel di Sulawesi Barat pun kembali mengalami penurunan, dimana beberapa perusahaan penginapan akhirnya tutup pada 2018.

\section{Pengembangan infrastruktur pariwisata: restoran/rumah makan}

Restoran atau rumah makan juga merupakan fasilitas penting yang dapat menunjang pariwisata suatu daerah. Banyaknya pilihan tempat untuk makan beserta kenyamanan, pelayanan, serta menu-menu yang ditawarkan dapat menjadi daya tarik bagi para turis untuk datang dan tinggal berlamalama di suatu daerah. Faktor inipun menjadi krusial untuk menciptakan kesan baik bagi para wisatawan, baik domestik maupun mancanegara terhadap suatu daerah dan tempat-tempat wisata yang mereka kunjungi, sehingga membuka potensi untuk kunjungan berulang. Di wilayah Sulawesi Barat sendiri terdapat ratusan restoran serta rumah makan yang tersebar di enam Kabupaten. Peningkatan jumlah restoran/rumah makan paling drastis terjada pada 2016 dimana 313 restoran pada 2015 meningkat menjadi 361 
restoran (BPS, 2017a). Jumlah ini meningkat menjadi 373 pada 2017, dan pada 2018 tidak ada penambahan restoran/rumah makan baru di Sulawesi Barat (BPS, 2019).

Tabel 3: Jumlah restoran/rumah makan di wilayah Sulawesi Barat 2015-2018

\begin{tabular}{|c|c|c|c|c|}
\hline $\begin{array}{c}\text { Kabupaten/K } \\
\text { ota }\end{array}$ & \multicolumn{4}{|c|}{ Jumlah Restoran/Rumah Makan } \\
\cline { 2 - 5 } & $\mathbf{2 0 1 5}$ & $\mathbf{2 0 1 6}$ & $\mathbf{2 0 1 7}$ & $\mathbf{2 0 1 8}$ \\
\hline Majene & 2 & 13 & 17 & 17 \\
\hline $\begin{array}{c}\text { Polewali } \\
\text { Mandar }\end{array}$ & 88 & 37 & 40 & 40 \\
\hline Mamasa & 24 & 27 & 28 & 28 \\
\hline Mamuju & 150 & 171 & 175 & 175 \\
\hline Pasangkayu & 38 & 53 & 53 & 53 \\
\hline $\begin{array}{c}\text { Mamuju } \\
\text { Tengah }\end{array}$ & 11 & 60 & 60 & 60 \\
\hline Total & 313 & 361 & 373 & 373 \\
\hline
\end{tabular}

Sumber: Dinas Pariwisata Sulawesi Barat

\section{Peningkatan Jumlah Wisatawan Mancanegara}

Dalam beberapa tahun terakhir, sebenarnya telah terjadi peningkatan yang cukup signifikan dalam jumlah wisatawan mancanegara di wilayah Sulawesi Barat. Dari sejak Masyarakat ASEAN pertama kali dicanangkan pada 2015, jumlah wisatawan, khususnya wisatawan asing meningkat hingga beberapa kali lipat. Fenomena ini jelas terlihat dari data yang dikeluarkan oleh Dinas Pariwisata Provinsi Sulawesi Barat, dimana jumlah turis asing pada tahun 2015 yang hanya 50 orang meningkat hingga 336 orang pada tahun 2016 (BPS, 2017b). Jumlah ini kemudian meningkat dua kali lipat hingga 723 orang pada 2017, meskipun akhirnya turun kembali hingga 550 orang pada tahun 2018 (BPS, 2019a). 
Tabel 4: Jumlah wisatawan asing dan domestik di wilayah Sulawesi Barat 2015-2018

\begin{tabular}{|c|c|c|c|c|}
\hline $\begin{array}{c}\text { Jumlah } \\
\text { Wisatawan }\end{array}$ & $\mathbf{2 0 1 5}$ & $\mathbf{2 0 1 6}$ & $\mathbf{2 0 1 7}$ & $\mathbf{2 0 1 8}$ \\
\hline Mancanegara & 50 & 336 & 723 & 550 \\
\hline Domestik & 30337 & 164251 & 385557 & 442563 \\
\hline
\end{tabular}

Sumber: Dinas Pariwisata Provinsi Sulawesi Barat

Data jumlah wisatawan asing yang melonjak secara signifikan seolah menunjukkan bahwa momentum Masyarakat ASEAN 2015 diikuti oleh peningkatan besar-besaran dalam aspek pariwisata di Sulawesi Barat. Dari data tersebut, sekilas orang bisa saja menyimpulkan bahwa Sulawesi Barat adalah daerah yang sukses mewujudkan visi konektivitas Masyarakat ASEAN 2015 dalam bentuk pengembangan pariwisata yang berdaya tarik internasional, serta inklusif bagi warga mancanagera, baik di tingkat regional maupun internasional. Namun jika ditelusuri lebih jauh, data tersebut sebenarnya kurang cukup untuk merepresentasikan gambaran utuh pariwisata di Sulawesi Barat serta pengembangan pariwisata di wilayah ini secara komprehensif pasca 2015.

\section{Pariwisata berbasis event}

Jumlah wisatawan yang membludak di Sulawesi Barat, baik domestik maupun mancanegara sebagian besar dipengaruhi oleh acara atau event khusus yang diselenggarakan dalam beberapa tahun terakhir. Dalam hal ini, satu event yang paling dominan adalah Polewali Mandar International Folk and Art Festival (PIFAF), suatu pagelaran seni budaya yang melibatkan beberapa negara dari berbagai belahan dunia dan secara rutin diselengarakan di Kabupaten Polewali Mandar sejak 2016. PIFAF sendiri diprakarsai oleh Pemerintah Kabupaten Polewali Mandar, bersama Dinas Pariwisata dan didukung oleh Kementrian Pariwisata Republik Indonesia, International Council 
of Organizations of Folklore Festivals and Folk Arts (CIOFF) dan UNESCO. Dapat dikatakan bahwa acara PIFAF memberikan sumbangsih paling besar dalam peningkatan jumlah wisatawan asing di Sulawesi Barat pasca 2015. Berdasarkan data rataan lama menginap per harinya, rata-rata turis asing datang dan menginap serta menghabiskan waktu paling lama di sekitar bulan Agustus dan September, yaitu bulan-bulan dimana PIFAF biasanya diselenggarakan setiap tahun.

Tabel 5: Rataan lama menginap wisatawan asing(hari) di Sulawesi Barat 2016-2018

\begin{tabular}{|l|l|l|l|}
\hline Bulan & $\mathbf{2 0 1 6}$ & $\mathbf{2 0 1 7}$ & $\mathbf{2 0 1 8}$ \\
\hline Januari & 0,01 & 2,83 & 6,00 \\
\hline Februari & 0,00 & 2,31 & 1,00 \\
\hline Maret & 0,00 & 2,31 & 1,00 \\
\hline April & 0,00 & 2,67 & 1,67 \\
\hline Mei & 0,00 & 19,75 & 0,00 \\
\hline Juni & 0,00 & 13,00 & 1,00 \\
\hline Juli & 0,00 & 3,09 & 2,26 \\
\hline Agustus & 0,04 & 2,54 & 25,23 \\
\hline September & 0,04 & 17,56 & 2,77 \\
\hline Oktober & 0,00 & 3,00 & 8,50 \\
\hline November & 0,00 & 1,40 & 1,00 \\
\hline Desember & 0,00 & 0,00 & 1,10 \\
\hline
\end{tabular}

Sumber: Badan Pusat Statistik(BPS), Survei Hotel Tahunan

Dari data tahun 2016, jelas terlihat bahwa wisatawan mancanegara menginap dan tinggal lebih banyak pada bulan Agustus dan September, dimana PIFAF pertama kali diselenggarakan (30 Agustus-5 September). Di tahun 2017, data jauh lebih berimbang dimana rataan menginap wisatawan asing tersebar dan terkonsetrasi di bulan-bulan tertentu seperti Mei, Juni, dan September. Namun pada 2018, data kembali menunjukkan trend yang sama 
dengan 2016, bahkan dengan perbandingan yang jauh lebih kontras, dimana rataan wisatawan asing yang menginap di wilayah Sulawesi Barat per harinya di bulan Agustus jauh lebih tinggi dibanding bulan-bulan yang lainnya. Dan di bulan juga PIFAF 2018 di selenggarakan (1-6 Agustus ).

Selain dari data rataan waktu menginap, data jumlah wisatawan asing per kabupaten juga menunjukkan kecenderungan yang serupa. Dalam beberapa tahun terakhir, Kabupaten Polewali Mandar selalu menjadi tujuan favorit banyak pengunjung mancanegara di Sulawesi Barat. Jumlah wisatawan mancanegara di Polewali Mandar pun hampir selalu lebih besar dibandingkan kabupaten

lainnya.

Tabel 6: Jumlah wisatawan mancanegara

per kabupaten di Sulawesi Barat 2016-2018

\begin{tabular}{|c|c|c|c|}
\hline \multirow{2}{*}{ Kabupaten } & \multicolumn{3}{|c|}{ Jumlah wisatawan } \\
mancanegara \\
\cline { 2 - 4 } & $\mathbf{2 0 1 6}$ & $\mathbf{2 0 1 7}$ & $\mathbf{2 0 1 8}$ \\
\hline Majene & 9 & 101 & 119 \\
\hline $\begin{array}{c}\text { Polewali } \\
\text { Mandar }\end{array}$ & 252 & 316 & 116 \\
\hline Mamasa & 15 & 105 & 105 \\
\hline Mamuju & 4 & 61 & 70 \\
\hline Pasangkayu & 30 & 78 & 78 \\
\hline $\begin{array}{c}\text { Mamuju } \\
\text { Tengah }\end{array}$ & 26 & 62 & 62 \\
\hline Total & 336 & 723 & 550 \\
\hline
\end{tabular}

Sumber: Dinas Pariwisata Sulawesi Barat

Data tersebut menunjukkan bahwa jumah wisatawan mancanegara di Kabupaten Polewali Mandar (Polman) pada tahun 2016 (252 orang) dan 2017 (316) jauh lebih besar, bahkan sampai beberapa kali lipat dari kabupaten- 
kabupaten lainnya. Kecenderungan ini mulai sedikit berubah pada 2018, dimana perimbangan jumlah turis asing antar kabupaten mulai terlihat, meskipun sekali lagi Polman, bersama Majene dan Mamasa tetap menjadi tujuan favorit untuk pariwisata. Dari data tersebut, maka tidak berlebihan jika disimpulkan bahwa dibalik peningkatan jumlah wisatawan mancanegara di Sulawesi Barat dalam beberapa tahun terakhir, konsentrasi cukup besar terdapat di wilayah Polewali Mandar, kabupaten dimana PIFAF diselenggarakan.

\subsection{Analisis Evaluatif}

Momentum Masyarakat ASEAN 2015 diikuti oleh peningkatan jumlah infrastruktur pariwisata di Sulawesi Barat, khususnya fasilitas akomodasi berupa hotel, penginapan serta rumah makan, dan restoran. Namun jumlah penambahan ini tidak cukup signifikan, khususnya pada periode 2017 hingga 2018, dimana tidak ada penambahan restoran baru, dan bahkan terjadi penurunan pada jumlah hotel dan penginapan. Akselerasi pertumbuhan yang relatif standar ini menandakan bahwa penambahan infrastruktur yang terjadi merupakan refleksi dari proses pembangunan yang berjalan secara normal di masyarakat Sulawesi Barat. Dalam hal ini, sama sekali belum dapat dikatakan bahwa pembangunan tersebut didorong oleh urgensi penerapan agenda Masyarakat ASEAN 2015, baik di tingkat pemerintah maupun masyarakat/swasta.

Persoalan berikutnya adalah pembangunan belum secara signifikan terjadi di ranah-ranah paling mendasar dari pengembangan pariwisata itu sendiri. Dalam hal ini, pembangunan belum secara komprehensif menyentuh pengembangan infrastruktur di berbagai objek wisata, penyediaan fasilitas yang lebih baik, serta peningkatan daya tarik objek wisata di Sulawesi Barat. Selain itu, salah satu masalah yang paling fundamental tentu saja tidak terlepas dari isu aksesibilitas. Menurut Pengakuan Kepala Dinas Pariwisata Sulawesi Barat, Farid Wajdi bahwa beberapa daerah pariwisata, masih sulit untuk diakses kendaraan, maka dari itu pembangunan infrastruktur jalan dan 
transportasi harus lebih diprioritaskan (Amirullah, 2019). Hal ini menjadi krusial karena kemudahan akses serta transportasi adalah denyut nadi dari konektivitas, yang jika tidak terpenuhi, maka visi dari Masyarakat ASEAN dalam sektor pariwisata tentu akan sulit untuk terealisasi.

Lebih jauh, melalui wawancara yang dilakukan dengan Farid Wajdi selaku Kepala Dinas Pariwisata Sulawesi Barat, beberapa isu terkait pariwisata daerah ini diangkat ke permukaan. Pertama, Farid membenarkan bahwa memang terdapat kecenderungan pariwisata berbasis event per event dalam menarik minat wisatawan mancanegara ke Sulawesi Barat. "Memang pariwisata kita masih mengandalkan event-event untuk menarik turis asing" tandasnya, sambil kembali menyebutkan PIFAF sebagai contoh utama (Wajdi, F, 2019, komunikasi personal, 21 Mei). Sebagai gambaran lebih lanjut, PIFAF menjadi daya tarik wisatawan asing karena dapat menggandeng para penampil-penampil dari berbagai negara dalam satu event pagelaran seni yang bisa dibilang cukup besar. Di satu sisi, beberapa wisatawan tertarik untuk datang dan menyaksikan PIFAF bersama rekan-rekan senegaranya yang menjadi penampil. Di sisi lain, para penampil sendiri yang jumlahnya bisa sampai puluhan orang berpartisipasi dalam penampilan seni sekaligus menjadi wisatawan yang menghabiskan waktu untuk melakukan eksplorasi tempat-tempat wisata di wilayah Sulawesi Barat.

Salah satu aspek yang sangat positif dari kegiatan PIFAF adalah dalam kurun waktu tiga tahun terhitung sejak pertama kali dihelat (2016-2018), selalu ada perwakilan dari negara-negara ASEAN yang ikut berpartisipasi. Sebagai suatu event yang menggandeng berbagai negara di seluruh dunia, adanya perwakilan dari kawasan sendiri, yaitu Asia Tenggara bersanding dengan perwakilan negara-negara dari Asia Timur dan Eropa tentu merupakan sinyal yang baik. Hal ini dapat dikatakan sebagai langkah awal yang cukup tepat untuk membuka jalan konektivitas ASEAN, paling tidak dalam kerangka membangun kesan yang baik serta promosi wisata Sulawesi Barat bagi wisatawan atau calon wisatawan dari Asia Tenggara. 
Tabel 7: Negara-negara penampil PIFAF 2016-2018

\begin{tabular}{|c|c|c|c|}
\hline Edisi PIFAF & 2016 & 2017 & 2018 \\
\hline $\begin{array}{c}\text { Penampil } \\
\text { Mancanegara }\end{array}$ & $\begin{array}{l}\text { Rumania, India, } \\
\text { Korea Selatan, } \\
\text { Malaysia, Rusia } \\
\text { (Tribratanews } \\
\text { PoldaSulbar, } \\
2016 \text { ) }\end{array}$ & $\begin{array}{l}\text { Inggris, } \\
\text { Spanyol, } \\
\text { Finlandia, } \\
\text { Belanda, Rusia, } \\
\text { Portugal, } \\
\text { Jerman, } \\
\text { Prancis, } \\
\text { Vietnam, } \\
\text { China, Hong } \\
\text { Kong, } \\
\text { Maroko(CNN } \\
\text { Indonesia, } \\
\text { 2017) }\end{array}$ & $\begin{array}{l}\text { Latvia, Polandia, } \\
\text { Kroasia, China } \\
\text { Taipei, Thailand, } \\
\text { Meksiko } \\
\text { (Tribunnews, } \\
\text { 2018) }\end{array}$ \\
\hline
\end{tabular}

Dari data tersebut terlihat bahwa Vietnam, Malaysia, dan Thailand bergantian berpartisipasi di PIFAF 2016, 2017 dan 2018. Hadirnya representasi dari ASEAN yang tentunya juga berperan, baik sebagai wisatawan, maupun menarik wisatawan tentunya penting dalam upaya merintis jalan untuk mewujudkan konektivitas Masyarakat ASEAN. Sayangnya trend ini terhenti pada PIFAF 2019 yang tidak menghadirkan wakil dari negara anggota ASEAN, meskipun mampu untuk mendatangkan perwakilan dari Timor Leste sebagai negara tetangga. Oleh karena itu, kedepannya penting untuk semakin mendorong partisipasi negara-negara ASEAN dalam eventevent pariwisata di Sulawesi Barat.

Berkaca dari fenomena ini juga, maka penguatan dari aspek event perlu untuk diupayakan di setiap daerah di Sulawesi Barat. Tidak hanya di Polewali Mandar, namun kabupaten-kabupaten lain perlu untuk menggalakkan acara- 
acara atau kegiatan yang dapat menarik wisatawan dari luar. "Setiap kabupaten harus memiliki event nya masing-masing yang dapat menjadi penciri atau trademark dari daerah tersebut" kata Farid (Wajdi, F, 2019a, komunikasi personal, $21 \mathrm{Mei}$. Paling tidak kegiatan-kegiatan semacam PIFAF bisa menjadi stimulus bagi para wisatawan untuk mengenal objek-objek wisata di Sulawesi Barat. "Kegiatan, kegiatan semacam itu bisa menjadi semacam penyangga yang efektif, karena tidak mungkin para wisatawan yang datang, dan tinggal misalkan tiga hari sampai seminggu hanya fokus pada event saja, tapi pasti mereka juga tertarik untuk berkunjung ke tempat-tempat menarik yang ada di sekitarnya", lanjut Farid (Wajdi, F, 2019b, komunikasi personal, 21 Mei). Di Sulawesi Barat sendiri, disamping Kabupaten Polewali Mandar yang sudah dikenal dengan beberapa event andalan, seperti PIFAF sendiri, Sandeq Race, Festival Sungai Mandar dan sebagainya, kabupaten-kabupaten lain pun perlu digali lebih jauh potensinya seperti Mamasa dengan Festival Gandang Dewata, dan Majene yang sebenarnya memiliki potensi dalam penyelenggaraan kegiatan wisata berbasis historis dan kota tua (Wajdi, F, 2019c, komunikasi personal, $21 \mathrm{Mei)}$.

Selain itu, dalam menyambut momentum Masyarakat ASEAN, sebenarnya Pemerintah Provinsi Sulawesi Barat bersama Dinas Provinsi Sulawesi Barat masih dalam tahap pemetaan, serta penjajakan potensi wisata daerah ini. Di wilayah Sulawesi Barat, terdapat ratusan objek-objek wisata potensial, baik yang sudah terjamah secara meluas oleh masyarakat maupun yang belum. Dan objek-objek wisata ini telah terpetakan dalam sembilan (9) kategori utama, antara lain wisata bahari, wisata budaya, wisata alam, wisata buatan, dan sebagainya.

Tabel 8: Pemetaan objek pariwisata Sulawesi Barat

\begin{tabular}{|c|c|c|c|c|c|c|c|}
\hline Kategor & \multicolumn{6}{|c|}{ Jumlah Objek Wisata } & Tota \\
\hline $\begin{array}{l}\text { i Objek } \\
\text { Wisata }\end{array}$ & $\begin{array}{l}\text { Majen } \\
\text { e }\end{array}$ & $\begin{array}{l}\text { Polma } \\
\text { n }\end{array}$ & $\begin{array}{l}\text { Mamas } \\
\text { a }\end{array}$ & $\begin{array}{l}\text { Mamuj } \\
\mathbf{u}\end{array}$ & $\begin{array}{l}\text { Pasangkay } \\
\text { u }\end{array}$ & $\begin{array}{l}\text { Mamuj } \\
\mathbf{u}\end{array}$ & 1 \\
\hline
\end{tabular}




\begin{tabular}{|l|l|l|l|l|l|l|l|}
\hline $\begin{array}{l}\text { Wisata } \\
\text { Alam }\end{array}$ & 2 & 20 & 43 & 23 & 22 & 31 & 141 \\
\hline $\begin{array}{l}\text { Wisata } \\
\text { Bahari }\end{array}$ & 8 & 12 & - & 15 & 25 & 23 & 83 \\
\hline $\begin{array}{l}\text { Wisata } \\
\text { Budaya }\end{array}$ & 6 & 11 & 62 & 7 & 2 & 8 & 96 \\
\hline $\begin{array}{l}\text { Wisata } \\
\text { Religi }\end{array}$ & 1 & 2 & 1 & - & 2 & 1 & 7 \\
\hline $\begin{array}{l}\text { Wisata } \\
\text { Agro }\end{array}$ & - & 5 & 1 & - & 2 & 11 & 19 \\
\hline $\begin{array}{l}\text { Wisata } \\
\text { Sejarah }\end{array}$ & 6 & 9 & - & - & 2 & - & 17 \\
\hline $\begin{array}{l}\text { Wisata } \\
\text { Buatan }\end{array}$ & 1 & 2 & - & 2 & - & & \\
\hline $\begin{array}{l}\text { Wisata } \\
\text { Kuliner }\end{array}$ & 2 & 1 & - & 1 & 1 & - & 5 \\
\hline $\begin{array}{l}\text { Wisata } \\
\text { Minat } \\
\text { Khusus }\end{array}$ & 2 & - & - & - & - & - & 5 \\
\hline
\end{tabular}

Sumber: Dinas Pariwisata Sulawesi Barat

Terdapat 375 objek wisata yang berhasil dipetakan dalam sembilan kategori, dan potensi pariwisata terbesar di Sulawesi Barat masih terdapat pada wisata alam, wisata bahari, dan wisata budaya. Mengingat Sulawesi Barat merupakan daerah dengan kondisi alam yang masih tergolong asri, kebudayaan yang masih kental di masyarakatnya, serta wilayah pesisir yang luas, maka tidak mengherankan jika sebagian besar objek wisata masuk ke dalam tiga kategori tersebut. Maka dari itu, dapat dikatakan fokus dari 
pembangunan awal pariwisata Sulawesi Barat dalam sinergi dengan agenda Masyarakat ASEAN sudah selayaknya difokuskan pada pengembangan wisata alam, pesisir dan budaya. Tambahan pula, (11) objek wisata terfavorit Sulawesi Barat memang menonjolkan daya tarik dari aspek-aspek ini.

Tabel 9: Objek wisata terfavorit di Sulawesi Barat

\begin{tabular}{|c|c|c|}
\hline & Destinasi Wisata Favorit & Lokasi \\
\hline & 1. Pantai Dato & Majene \\
\hline & 2. Pantai Barane & Majene \\
\hline & 3. Pulau Gusung Toraya & Polewali Mandar \\
\hline & 4. Air Terjun Liawan & Mamasa \\
\hline & $\begin{array}{l}\text { 5. Desa Wisata Balla } \\
\text { Tumuka }\end{array}$ & Mamasa \\
\hline & $\begin{array}{l}\text { 6. Taman Wisata } \\
\text { Gentungan }\end{array}$ & Mamuju \\
\hline & 7. Pulau Karampuang & Mamuju \\
\hline & $\begin{array}{l}\text { 8. Pantai Tanjung Batu } \\
\text { Oge }\end{array}$ & Pasangkayu \\
\hline & $\begin{array}{l}\text { 9. Pantai dan Pulau } \\
\text { Kabunong }\end{array}$ & Mamuju Tengah \\
\hline $\begin{array}{l}\text { Sumber: } \\
\text { Pariwisata }\end{array}$ & $\begin{array}{l}10 . \\
\text { antai Batu Rede }\end{array}$ & Mamuju Tengah \\
\hline Barat & $\begin{array}{l}11 . \\
\quad \text { ir Terjun Kalando }\end{array}$ & Mamuju Tengah \\
\hline
\end{tabular}

Berkaca dari data serta fenomena tersebut, dapat dikatakan bahwa langkah lain yang patut diupayakan adalah memfokuskan pembangunan awal pada objek-objek unggulan terlebih dahulu. Dalam hal ini, pembangunan dapat secara realistis dilakukan pada beberapa objek utama, sehingga dapat segera dipromosikan secara masif dan ditawarkan ke dunia internasional. Sebagai contoh, fokus pada pembangunan fasilitas pelayanan yang lebih baik, 
peningkatan estetika melalui renovasi objek wisata, serta peningkatan aksebilitas dapat diarahkan ke 11 objek wisata unggulan diatas sebagai langkah awal. Dengan dikenalnya Sulawesi Barat, paling tidak melalui beberapa objek wisata yang representatif dan tersandarisasi, maka akan membuka jalan untuk mewujudkan konektivitas pariwisata secara menyeluruh.

Selain melakukan pemetaan, Dinas Pariwisata Provinsi Sulawesi Barat juga masih dalam tahap untuk melakukan penguatan dari dalam. "Masyarakat ASEAN membuka peluang konektivitas yang sangat luar biasa, namun sebelum menuju kesana kami dalam proses penguatan kelembagaan serta penguatan internal", kata Farid (Wajdi, F, 2019d, komunikasi personal, $21 \mathrm{Mei})$. Sebelum melangkah lebih jauh, perlu untuk diingat bahwa ujung dari visi Masyarakat ASEAN adalah peningkatan taraf hidup dan kesejahteraan warga ASEAN. Maka dari itu, penting untuk memastikan bahwa pembangunan sentra pariwisata akan diikuti oleh pemberdayaan masyarakat sekitar, sehingga keuntungan dari segi ekonomi akan lebih banyak dirasakan oleh mereka. Dalam hal ini, banyak dari masyarakat Sulawesi Barat, khususnya mereka yang hidup di pesisir, maupun mereka yang berada dalam tingkat ekonomi menengah ke bawah, masih belum teredukasi dengan sempurna, baik dalam manajemen pelayanan pariwisata, maupun bagaimana melakukan kapitalisasi potensi pariwisata di daerah mereka. Oleh karenanya, sebelum terjun penuh dalam pemasaran pariwisata di tingkat internasional, sangat penting untuk menguatkan fondasi pariwisara dari dalam dengan pembangunan dalam dua aspek utama, yaitu infrastruktur pariwisata dan sumber daya manusia (SDM), atau dalam hal ini masyarakat Sulawesi Barat di akar rumput sebagai aktor utama dalam pengelolaan sektor pariwisata tersebut. "Pembangunan pariwisata harus berorientasi ke masyarakat, dan masyarakat yang harus mendapat dampak ekonomi dari pembangunan tersebut”, lanjut Farid (Wajdi, F, 2019e, komunikasi personal, 21 Mei).

\section{KESIMPULAN}


Momentum Masyarakat ASEAN 2015 tidak serta merta diikuti dengan pembangunan infrastruktur pariwisata secara komprehensif dan signifikan di wilayah Sulawesi Barat, meskipun terdapat sedikit peningkatan dalam jumlah penginapan dan restoran selama periode 2015-2018. Dalam hal ini, Pemerintah Provinsi bersama dengan Dinas Pariwisata Sulawesi Barat masih dalam tahapan pemetaan potensi pariwisata, penguatan di ranah internal, dan perencanaan sistem pariwisata berbasis masyarakat dalam menghadapi visi konektivitas Masyarakat ASEAN 2015. Langkah strategis yang selanjutnya perlu dilakukan antara lain adalah perencanaan pembangunan infrastruktur dan fasilitas pariwisata serta perbaikan aksesibilitas pariwisata, yang dapat ditargetkan untuk beberapa objek wisata unggulan di Sulawesi Barat sebagai tahap awal. Di samping itu, perlu adanya program peningkatan kapasitas masyarakat secara merata dan berkelanjutan dalam rangka edukasi manajemen pariwisata, serta pembangunan sumber daya manusia (SDM) di sektor pariwisata di Sulawesi Barat.

Selain itu, terdapat peningkatan yang cukup signifikan dalam jumlah wisatawan mancanagera selama tiga tahun terhitung sejak diberlakukannya Masyarakat ASEAN 2015. Peningkatan ini sebagian besar dipicu oleh acara atau event berskala internasional yang diselenggarakan di Sulawesi Barat, contohnya seperti PIFAF di Polewali Mandar. Meskipun tidak secara sempurna merepresentasikan visi dari konektivitas ASEAN, penerapan pariwisata berbasis event/acara ini sebenarnya merupakan instrumen awal yang cukup efektif serta strategis dalam menjaring wisatawan mancanegara sekaligus melakukan promosi objek-objek wisata di wilayah Sulawesi Barat kepada komunitas internasional. Oleh karena itu, langkah berikutnya perlu dilakukan adalah peningkatan dalam penyelenggaraan event-event internasional khususnya di kabupaten kabupaten lain, agar tercipta pemerataan dalam kunjungan wisatawan mancanagera dan promosi objek wisata di setiap daerah di Sulawesi Barat. Tambahan pula, sebagai upaya integral dalam mewujudkan agenda Masyarakat ASEAN, sangat perlu untuk secara khusus meningkatkan partisipasi negara-negara ASEAN dalam event-event tersebut. Langkah ini 
dapat dilakukan dengan secara rutin mengajak negara-negara di Asia Tenggara untuk berpartisipasi serta menambah kuota peserta atau tamu undangan dari negara ASEAN dalam event-event tersebut.

\section{DAFTAR PUSTAKA}

Akkapin, S. \& Srithamasak, N. (2019). An Analysis of Tourism Research in the Context of ASEAN Community. University of the Thai Chamber of Commerce Journal Humanities and Social Sciences, 37(4), 1-19.

Amirullah (2019) Sulbar Prioritaskan Penataan Tiga Objek Unggulan https://makassar.antaranews.com/berita/128811/sulbarprioritaskan-penataan-tiga-objek-wisata-unggulan

ASEAN (2011) Master Plan on ASEAN Connectivity. Tersedia pada: http://www.asean.org/storage/images/ASEAN_RTK_2014/4_Master_Pla n_on_ASEAN_Connectivity.pdf

Badan Pusat Statistik (2017) Provinsi Sulawesi Barat Dalam Angka 2017. Sulawesi Barat: BPS

Badan Pusat Statistik (2018) Provinsi Sulawesi Barat Dalam Angka 2018. Sulawesi Barat: BPS

Badan Pusat Statistik (2019) Provinsi Sulawesi Barat Dalam Angka 2019. Sulawesi Barat: BPS

Bennett, A. (2008) Process Tracing: A Bayesian Perspective In Box-Steffensmer, J.M., Brady, H. E., \& Collier, D. (Eds.), The Oxford Handbook of Political Methodology. Oxford: Oxford University Press

Bong, A. \& Premaratne, G. (2018) Regional Integration and Economic Growth in Southeast Asia. SAGE 19 (6): 1403-1415 
Castaldi, R. (2007). A federalist framework theory of European Integration.Centro Studi di Federalismo

CNN Indonesia (2017) Polewali Mandar Gelar International Folk and Art Festival https://www.cnnindonesia.com/gaya-hidup/20170729161949307-231196/polewali-mandar-gelar-internasional-folk-and-art-festival

Dinas Pariwisata Provinsi Sulawesi Barat (2018) Pemetaan Pariwisata Sulawesi Barat. Mamuju: Pariwisata Sulawesi Barat

Illievski, N.L. (2015) The Concept of Political Integration: The Perspective of Neofunctionalist Theory. Journal of Liberty and International Affairs 1(1): $1-14$

Haas, E. (1968) The Uniting of Europe. Stanford: Stanford University Press

Rosamond, B. (2000): Theories of European Integration. New York: Palgrave

Fandeli, C. (1995) Dasar-Dasar Manajemen Kepariwisataan. Yogyakarta: Penerbit Liberty

Goeldner, C. R. \& Ritchie, J.R.B. (2009) Tourism Principles, Practices, Philosophies. New Jersey: John Wiley \& Sons, Inc.

Heinonen, H. (2006) Regional integration and the state: The changing nature of sovereignty in South Africa and Europe. Tersedia pada: https://helda.helsinki.fi/bitstream/handle/10138/21770/regional.pdf?s equence $=2$

Kovacevic, B. (2013) Hidden Federalism: The Federal Experience in the processes of European Integrations. Beograd: Albatros Plus, 
Moenir, H.D. (2017) Implementasi ASEAN Tourism Strategic Plan 2011-2015 dalam Kebijakan Pariwisata Indonesia di masa Pemerintahan Jokowi. Andalas Journal of International Studies 6(1): 57-78

Moravcsik, A. (1991) Negotiating the Single European Act. In Keohane and Hoffmann (eds.) The New European Community. Decision making and Institutional Change. Boulder: Westview Press: 41-84

Moravcsik, A. (1998) The Choice for Europe. Social Purpose \& State Power fromMessina to Maastricht. London: UCL Press Limited

Nugroho, I. \& Negara, P. D. (2014) Pengembangan Desa Wisata Mengantisipasi Masyarakat Ekonomi ASEAN 2015 pada Prosiding Seminar \& Ekspose Hasil Penelitian dan Pengabdian Masyarakat 2014. Surabaya: Kementrian Pendidikan dan Kebudayaan Koordinasi Perguruan Tinggi Swasta Wilayah VII

Tribratanews (2016) Upacara Pembukaan PIFAF 2016 Dirangkaikan dengan Festival Budaya XII Polman https://tribratanews.sulbar.polri.go.id/upacara-pembukaan-pifaf-2016di-rangkaikan-dengan-festival-budaya-xll-polman/

Tribunnews (2018) Enam Negara Bakal Meriahkan PIFAF 2018 di Polewali Mandar https://makassar.tribunnews.com/2018/07/12/enam-negarabakal-meriahkan-pifaf-2018-di-polewali-mandar 